\title{
Influência da Procainamida sobre o Bloqueio Neuromuscular Produzido pelo Rocurônio e Investigação sobre o Mecanismo de Ação da Procainamida na Junção Neuromuscular* Influence of Procainamide on the Neuromuscular Blockade Caused by Rocuronium and Investigation on the Mechanism of Action of Procainamide on the Neuromuscular Junction
}

Thalita Duque Martins ${ }^{1}$ Yolanda Christina S. Loyola², Angélica de Fátima de Assunção Braga, TSA ${ }^{3}$

\section{RESUMO}

Martins TD, Loyola YCS, Braga AFA — Influência da Procainamida sobre o Bloqueio Neuromuscular Produzido pelo Rocurônio e Investigação sobre o Mecanismo de Ação da Procainamida na Junção Neuromuscular.

JUSTIFICATIVA E OBJETIVOS: A potencialização da procainamida sobre o bloqueio neuromuscular produzido pela d-tubocurarina já está comprovada, porém o mecanismo é controverso. O objetivo do estudo foi avaliar a influência da procainamida no bloqueio neuromuscular produzido pelo rocurônio e investigar os mecanismos desta interação.

MÉTODO: Foram utilizados 15 ratos (250 a $300 \mathrm{~g}$ ) em preparação descrita por Bülbring. Formaram-se os seguintes grupos $(n=5$ cada): procainamida - $20 \mu \mathrm{g} \cdot \mathrm{mL}^{-1}$ (Grupo l); rocurônio - $4 \mu \mathrm{g} \cdot \mathrm{mL}^{-1}$ (Grupo II) e rocurônio - $4 \mu \mathrm{g} \cdot \mathrm{mL}^{-1}$ e procainamida - $20 \mu \mathrm{g} \cdot \mathrm{mL}^{-1}$ (Grupo III). Avaliaram-se: 1) a amplitude das contrações musculares sob estimulação indireta em cada grupo, antes e após a adição dos fármacos; 2) os potenciais de placa terminal em miniatura (PPTM); 3) a eficácia da 4-aminopiridina na reversão do bloqueio neuromuscular. O mecanismo da interação foi estudado em Biventer cervicis $(n=5)$ e diafragma de rato desnervado $(n=5)$, observando-se a influência da procainamida na resposta à acetilcolina antes e após a adição da procainamida.

RESULTADOS: A procainamida isoladamente não alterou as respostas neuromusculares. O bloqueio produzido com o Grupo III foi de $68,6 \% \pm 7,1 \%$, com diferença significativa $(p=0,0067)$ em relação ao Grupo II (10,4\% $\pm 4,5 \%)$, revertido pela 4-aminopiridina. $A$ procainamida ocasionou aumento na freqüência dos PPTM, seguido de bloqueio revertido pela 4-aminopiridina. Em Biventer cervicis

${ }^{*}$ Recebido do (Received from) Departamento de Farmacologia da Faculdade de Ciências Médicas da Universidade Estadual de Campinas (FCM-UNICAMP), Campinas, $S P$

1. Mestre em Farmacologia pelo Departamento de Farmacologia da FCM da UNICAMP

2. Doutora em Farmacologia pelo Departamento de Farmacologia da FCM da UNICAMP

3. Professora Associada do Departamento de Anestesiologia da FCM da UNICAMP

Apresentado (Submitted) em 17 de março de 2006

Aceito (Accepted) para publicação em 8 de setembro de 2006

Endereço para correspondência (Correspondence to):

Dra. Thalita Duque Martins

Rua Dr. Shigeo Mori, 589

Cidade Universitária

13083-760 Campinas, SP

E-mail: tha_duque@yahoo.com.br

(c) Sociedade Brasileira de Anestesiologia, 2007 a procainamida aumentou a resposta à ação de contração da acetilcolina, resultado não observado com o diafragma desnervado. CONCLUSÕES: A procainamida potencializou o bloqueio produzido pelo rocurônio. As alterações observadas com PPTM e Biventer cervicis identificaram ação pré-sináptica. $O$ antagonismo da 4-aminopiridina sobre o bloqueio dos PPTM sugeriu dessensibilização dos receptores pela procainamida.

Unitermos: ANIMAL: rato; ANTIARRÍTMICOS: procainamida; BLOQUEADORES NEUROMUSCULARES, Não-despolarizantes: rocurônio; DROGAS: interação.

\section{SUMMARY}

Martins TD, Loyola YCS, Braga AFA — Influence of Procainamide on the Neuromuscular Blockade Caused by Rocuronium and Investigation on the Mechanism of Action of Procainamide on the Neuromuscular Junction.

BACKGROUND AND OBJECTIVES: It has already been proved that procainamide potentiates the neuromuscular blockade of $d$-tubocurarine; however, the mechanism of this potentiation is controversial. The aim of this study was to assess the influence of procainamide on the neuromuscular blockade produced by rocuronium and investigate the mechanisms of this interaction.

METHODS: Fifteen rats (250 to $300 \mathrm{~g}$ ) were used in the preparation described by Bülbring. They were divided in three groups ( $n=5$ each): procainamide - $20 \mu \mathrm{g} \cdot \mathrm{mL}^{-1}$ (Group I); rocuronium - $4 \mu \mathrm{g} \cdot \mathrm{mL}^{-1}$ (Group II); and rocuronium - $4 \mu \mathrm{g} \cdot \mathrm{mL}^{-1}$ and procainamide $-20 \mu \mathrm{g} \cdot \mathrm{mL}^{-1}$ (Group III). The following parameters were evaluated: 1) amplitude of muscle contractions under indirect stimulation, before and after the administration of the drugs; 2) miniature end plate potentials (MEPPS); and 3) the efficacy of 4-aminopyridine in reverting the muscular blockade. The mechanism of the interaction was studied in Biventer cervicis $(n=5)$ and in the denervated rat diaphragm $(n=5)$, observing the influence of procainamide in the response to acetylcholine. RESULTS: Procainamide alone did not change the neuromuscular responses. Group III presented a $68.6 \% \pm 7.1 \%$ blockade, which represented a statistically significant difference $(p=0.0067)$ when compared with Group II (10.4\% $\pm 4.5 \%)$, which was reverted by 4-aminopiridine. Procainamide increased the frequency of the MEPP, followed by a blockade that was reverted by 4-aminopiridine. In Biventer cervicis, procainamide increased the contraction in response to acetylcholine, which was not observed in the denervated diaphragm.

CONCLUSIONS: Procainamide potentiated the blockade caused by rocuronium. The changes observed with MEPP and Biventer cervicis identified pre-synaptic action. The antagonism of 4-aminopiridine on the blockade of the MEPP suggested receptor desensitization by procainamide.

Key Words: ANIMAL: rat; ANTI-ARRHYTHMICS: procainamide; DRUGS: interaction; NEUROMUSCULAR BLOCKERS, Nondepolarizing: rocuronium. 


\section{INFLUÊNCIA DA PROCAINAMIDA SOBRE O BLOQUEIO NEUROMUSCULAR PRODUZIDO PELO ROCURÔNIO E INVESTIGAÇÃO}

SOBRE O MECANISMO DE AÇÃO DA PROCAINAMIDA NA JUNÇÃO NEUROMUSCULAR

\section{INTRODUÇÃO}

$A^{p}$ procainamida, análogo sintético do anestésico local procaína foi desenvolvida para o tratamento de disritmias cardíacas ventriculares e supraventriculares, possui ação mais prolongada do que a procaína por causa da sua função amídica ser resistente à ação das esterases ${ }^{1}$.

Seu uso crônico pode levar ao desenvolvimento de anticorpos antinucleares com evidências bioquímicas da síndrome lúpica, o que constitui fator de impedimento para o emprego por via oral por tempo prolongado. No entanto, por via venosa ela tem sido útil para o tratamento de disritmias cardíacas ${ }^{1,2}$. Alguns relatos clínicos demonstraram que altas concentrações plasmáticas da procainamida, associadas a fatores que comprometem a transmissão neuromuscular, como doenças neuromusculares (miastenia gravis latente sem manifestações clínicas), fármacos como a amiodarona, diabete melito e insuficiência renal, podem ocasionar sintomas do tipo miastenialike ${ }^{3-5}$. Esses efeitos têm sido observados sem detecção de anticorpos anti-receptores de acetilcolina (ACh) ${ }^{2}$.

Embora existam muitos trabalhos buscando explicar tais efeitos, o mecanismo pelo qual a procainamida interfere na transmissão neuromuscular permanece sem elucidação até a atualidade ${ }^{6-10}$.

O esclarecimento do tipo de interação entre a procainamida e os bloqueadores neuromusculares não-despolarizantes utilizados na clínica é importante, possibilitando o uso seguro desses fármacos.

A potencialização dos efeitos da d-tubocurarina pela procainamida tem sido demonstrada ${ }^{11}$, porém ainda não existem estudos comparativos para demonstrar a interação da procainamida com outros bloqueadores neuromusculares atualmente empregados na prática clínica.

O rocurônio é um bloqueador neuromuscular não-despolarizante aminoesteróide, com duração de ação intermediária mas rápido início, característica que o diferencia dos demais bloqueadores não-despolarizantes e o torna um agente alternativo para a succinilcolina em situações de indução de seqüência rápida ${ }^{12-14}$

O objetivo deste estudo foi avaliar, em modelo experimental, o efeito da procainamida na transmissão neuromuscular e a sua influência no bloqueio neuromuscular produzido pelo rocurônio, investigando ainda o provável mecanismo da interação procainamida e rocurônio.

\section{MÉTODO}

Foi realizado estudo experimental obedecendo aos princípios éticos do Colégio Brasileiro de Experimentação Animal (COBEA) que foram aprovados pela Comissão de Ética em Experimentação Animal do Instituto de Biologia da Universidade Estadual de Campinas (UNICAMP).

Para avaliação do efeito da procainamida na transmissão neuromuscular e a influência no bloqueio neuromuscular produzido pelo rocurônio, usou-se a preparação nervo frênico-diafragma de rato, proposta por Bulbring ${ }^{15}$. Foram utilizados 15 ratos da linhagem Wistar, com peso entre 250 e $300 \mathrm{~g}$, sacrificados sob anestesia com hidrato de cloral a $10 \%$ (250 mg. $\mathrm{kg}^{-1}$ ), por via intraperitoneal, e sangria por secção dos vasos do pescoço. Os hemidiafragmas com os nervos frênicos correspondentes foram retirados e fixados em cuba contendo $40 \mathrm{~mL}$ de solução nutritiva de Tyrode com a seguinte composição em mM: $\mathrm{NaCl} 137 ; \mathrm{KCl} 2,7 ; \mathrm{CaCl}_{2}$ 1,8; $\mathrm{NaHCO}_{3} 11,9 ; \mathrm{MgCl}_{2}$ 0,25; $\mathrm{NaH}_{2} \mathrm{PO}_{4}$ 0,3 e glicose 11. A solução foi aerada constantemente com carbogênio $\left(95 \% \mathrm{O}_{2}\right.$ e $5 \% \mathrm{CO}_{2}$ ) e mantida a $37^{\circ} \mathrm{C}$. O nervo foi colocado sobre eletrodos de platina ligados a um estimulador Grass S48. O diafragma foi mantido por sua porção tendinosa sob tensão constante $(5,0 \mathrm{~g})$, através de fio ligado a transdutor isométrico Load Cell BG50 GMS, e submetido à estimulação indireta de $0,1 \mathrm{~Hz}$ de freqüência e duração de 0,2 ms, e as variações de tensão produzidas pelas contrações do diafragma foram registradas em fisiógrafo Gould RS 3400. Formaram-se três grupos ( $n=5$ cada), de acordo com o fármaco adicionado à preparação: Grupo I - procainamida (20 $\left.\mu \mathrm{g} \cdot \mathrm{mL}^{-1}\right)$; Grupo II - rocurônio (4 $\left.\mu \mathrm{g} \cdot \mathrm{mL}^{-1}\right)$; Grupo III rocurônio $\left(4 \mu \mathrm{g} \cdot \mathrm{mL}^{-1}\right)$ em preparação previamente exposta à procainamida $\left(20 \mu \mathrm{g} \cdot \mathrm{mL}^{-1}\right)$. No Grupo III (procainamidarocurônio), o rocurônio foi adicionado à preparação 30 minutos após a adição da procainamida. As respostas neuromusculares à estimulação indireta foram registradas durante 90 minutos após a adição dos fármacos. Para a reversão do bloqueio neuromuscular produzido pela associação procainamida-rocurônio, empregou-se 4-aminopiridina (4-AP) - $20 \mu \mathrm{g} \cdot \mathrm{mL}^{-1}$, adicionada à preparação 60 minutos após o BNM. Utilizou-se também a preparação nervo frênicodiafragma para o estudo dos efeitos da procainamida nos potenciais de placa terminal em miniatura.

As preparações Biventer cervicis de pintainho $(n=5)$ foram montadas de acordo com o método descrito por Ginsborg ${ }^{16}$ e mantidas em $5 \mathrm{~mL}$ de solução nutritiva de Krebs, composição em mM: ( $\mathrm{NaCl} 136 ; \mathrm{KCl} 5,0 ; \mathrm{CaCl}_{2} 2,5 ; \mathrm{KH}_{2} \mathrm{PO}_{4}$ 1,2; $\mathrm{NaHPO}_{3} 11,9$ e glicose 11,2 ), sob tensão de $0,5 \mathrm{~g}$, temperatura de $37^{\circ} \mathrm{C}$ e aeradas com carbogênio. Os músculos receberam estímulos indiretos com pulsos supramaximais (20-80 $\mathrm{V}$ de intensidade, $0,2 \mathrm{~ms}$ de duração e $0,1 \mathrm{~Hz}$ de freqüência). As respostas à acetilcolina $\left(10 \mu \mathrm{g} \cdot \mathrm{mL}^{-1}\right)$ foram registradas em fisiógrafo Gould RS 3400, antes e 30 minutos após a adição da procainamida $\left(20 \mu \mathrm{g} \cdot \mathrm{mL}^{-1}\right)$ à preparação, por 30 minutos.

Para a preparação hemidiafragma de rato cronicamente desnervado, os diafragmas foram desnervados ${ }^{17}$ e, 15 e 30 dias após, os hemidiafragmas esquerdos foram removidos e montados em cuba de $40 \mathrm{~mL}$ contendo solução nutritiva de Tyrode, sendo aerados e mantidos a $37^{\circ} \mathrm{C}$, como já descrito para preparações normais. As respostas a acetilcolina (4 $\mu \mathrm{g} \cdot \mathrm{mL}^{-1}$ ) foram registradas em fisiógrafo Gould RS 3400 antes e 30 minutos após a adição da procainamida (20 $\left.\mu \mathrm{g} \cdot \mathrm{mL}^{-1}\right)$. Os resultados foram expressos em média e desvio-padrão. Para análise estatística foram utilizados os tes- 
tes $t$ de Student. Assumiu-se nível significativo de $5 \%(\alpha=$ $5 \%$ ). O poder do teste foi calculado e obteve-se $\beta>20 \%$ (poder $>80 \%$ ).

\section{RESULTADOS}

A procainamida, na concentração estudada e empregada isoladamente em preparação nervo frênico-diafragma de rato, não causou redução na amplitude das respostas musculares à estimulação elétrica indireta (Figura 1).

Nas preparações expostas previamente a procainamida o bloqueio produzido pelo rocurônio foi de $68,6 \% \pm 7,1 \%$, com diferença significativa ( $p=0,0067)$ em relação ao produzido pelo rocurônio empregado isoladamente $(10,4 \% \pm 4,5 \%)$ (Figura 2). A 4-aminopiridina foi eficaz na reversão do bloqueio produzido pelo rocurônio em preparações expostas à procainamida (Figura 3).

Em preparação Biventer cervicis de pintainho, a procainamida $\left(20 \mu \mathrm{g} \cdot \mathrm{mL}^{-1}\right)$ causou aumento da ação de contração provocada pela acetilcolina, efeito não observado em preparação com hemidiafragma de rato cronicamente desnervado (Figuras 4 e 5).

Os efeitos sobre os potenciais de placa terminal em miniatura caracterizaram-se inicialmente por aumento na freqüência, e após cerca de 20 minutos da adição do fármaco, seguiuse o bloqueio. Esse efeito foi revertido pela 4-aminopiridina (Figura 6).

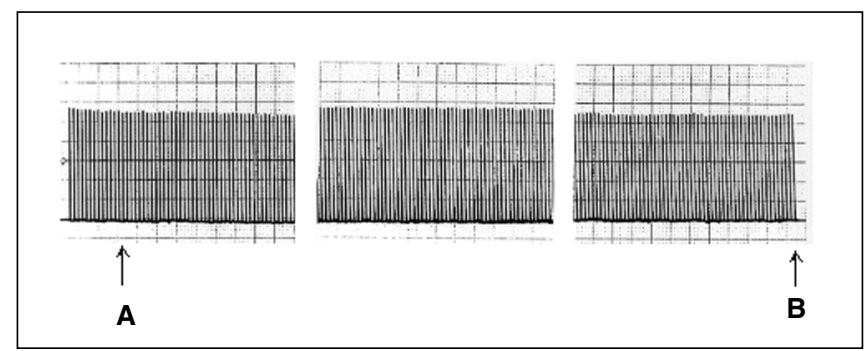

Figura 1 - Efeito da Procainamida $\left(20 \mu \mathrm{g} \cdot \mathrm{mL}^{-1}\right)$ nas Respostas Musculares à Estimulação Indireta em Preparação Nervo Frênico-Diafragma de Rato. A: adição de procainamida; B: 90 minutos após a adição de procainamida

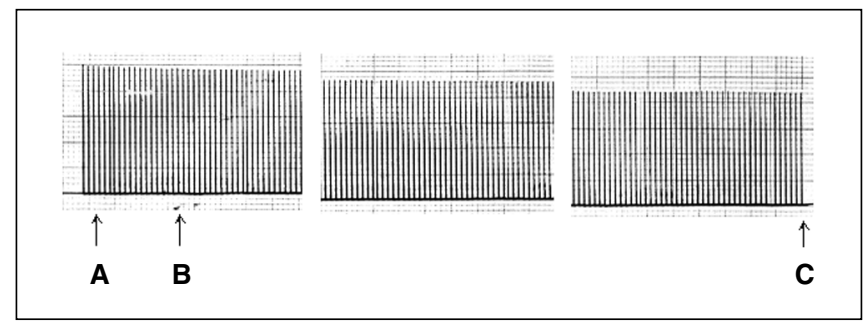

Figura 2 - Efeito do Rocurônio (4 $\left.\mu \mathrm{g} \cdot \mathrm{mL}^{-1}\right)$ nas Respostas Musculares a Estimulação Indireta em Preparação Nervo Frênico-Diafragma de Rato. A: controle; B: adição do rocurônio; C: 90 minutos após a adição de rocurônio

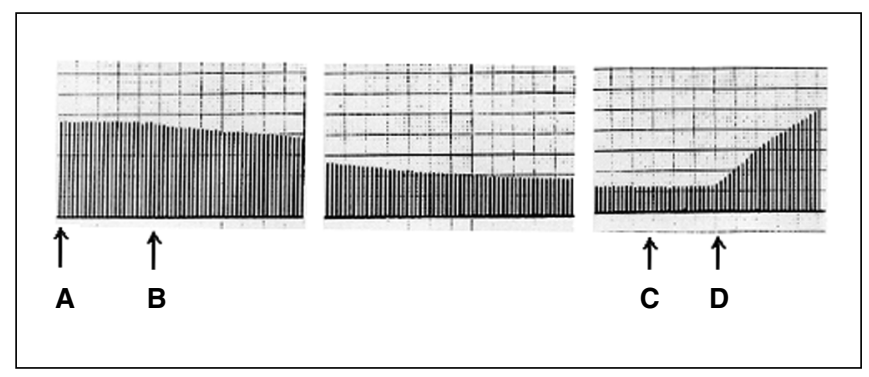

Figura 3 - Efeito do Rocurônio (4 $\left.\mu \mathrm{g} \cdot \mathrm{mL}^{-1}\right)$ nas Respostas Musculares à Estimulação Indireta em Preparação Nervo FrênicoDiafragma de Rato Expostas a Procainamida $\left(20 \mu \mathrm{g} \cdot \mathrm{mL}^{-1}\right)$. Efeito da 4-aminopiridina. A: controle obtido 30 minutos após a adição de procainamida; B: adição de rocurônio; C: bloqueio neuromuscular após adição de rocurônio; D: adição de 4 AP $\left(20 \mu \mathrm{g} \cdot \mathrm{mL}^{-1}\right)$

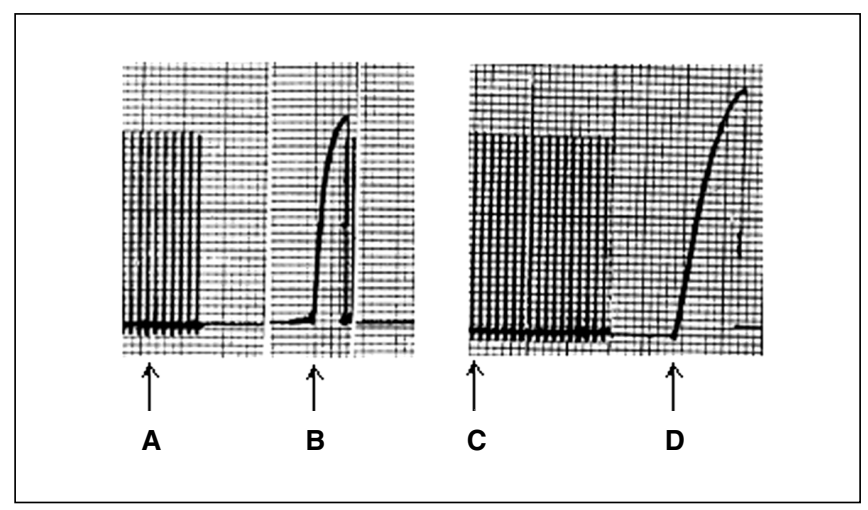

Figura 4 - Efeito da Procainamida $\left(20 \mu \mathrm{g} \cdot \mathrm{mL}^{-1}\right)$ sobre a Ação Contraturante da Acetilcolina $\left(10 \mu \mathrm{g} \cdot \mathrm{mL}^{-1}\right)$ em Preparação Biventer cervicis $(n=5)$, sob Estimulação Elétrica Indireta (freqüência $0,1 \mathrm{~Hz}$ e duração $0,2 \mathrm{~ms}$ ). A: controle; B: adição de acetilcolina; C: 30 minutos após a adição de procainamida, D: adição de acetilcolina

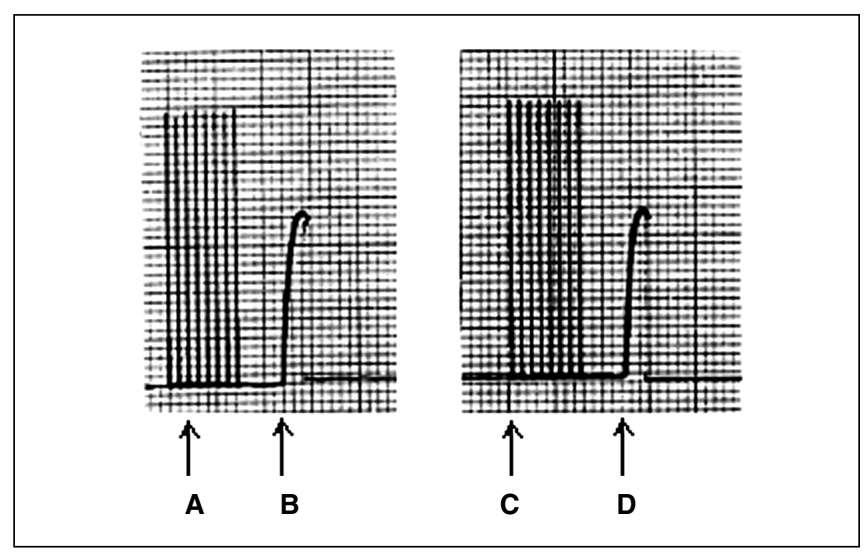

Figura 5 - Efeito da Procainamida $\left(20 \mu \mathrm{g} \cdot \mathrm{mL}^{-1}\right)$ sobre a Ação Contraturante da Acetilcolina $\left(4 \mu \mathrm{g} \cdot \mathrm{mL}^{-1}\right)$ em Preparação Diafragma Cronicamente Desnervado $(n=5)$. A: controle; B: adição de acetilcolina; C: 30 minutos após a adição de procainamida, D: adição de acetilcolina 




Figura 6 - Efeito da Procainamida $\left(20 \mu \mathrm{g} \cdot \mathrm{mL}^{-1}\right)$ nos Potenciais de Placa Terminal em Miniatura (PPTM) em Preparação Nervo Frênico-Diafragma de Rato. A: controle; B: 10 minutos após a adição de procainamida; C: 20 minutos após a adição de procainamida; D: efeito da 4 aminopiridina.

\section{DISCUSSÃO}

As Figuras 1 e 3 mostram que a procainamida isoladamente não possui efeito direto sobre a transmissão neuromuscular, sendo, porém, capaz de potencializar de maneira significativa o bloqueio causado pelo rocurônio. Esses resultados confirmaram estudos anteriores que demonstraram ser a procainamida capaz de potencializar os efeitos de bloqueadores neuromusculares como a d-tubocurarina ${ }^{11}$. A exposição prolongada à procainamida pode ocasionar o decréscimo do número de receptores da junção neuromuscular, com conseqüente diminuição da margem de segurança de receptores dessa região, o que constitui possível explicação para a potencialização do bloqueio neuromuscular produzido pelo rocurônio ${ }^{11}$.

Esse bloqueio foi antagonizado pela 4-aminopiridina, fármaco bloqueador de canais de $\mathrm{K}^{+}$da membrana celular, que na presença de potencial de ação deflagrado na membrana, proporciona maior aporte de acetilcolina na fenda sináptica. $\mathrm{O}$ bloqueio de canais de $\mathrm{K}^{+}$mantém por maior tempo a membrana despolarizada, com conseqüente abertura dos canais de $\mathrm{Ca}^{++}$voltagem-dependentes e maior entrada de $\mathrm{Ca}^{++}$para o interior do terminal pré-sináptico, que é diretamente proporcional à liberação do neurotransmissor. Inicialmente, o aumento da liberação de acetilcolina ocasionado pela 4-aminopiridina, com reversão eficaz do bloqueio neuromuscular produzido pela interação rocurônio-procainamida, permite inferir que o tipo de bloqueio observado seja do tipo competitivo.

Esses resultados são semelhantes aos de Lee e col. ${ }^{6}$ que ao estudarem em preparação com músculo Digitorum longus de rato os efeitos de diferentes concentrações de procainamida sobre potenciais de placa terminal em miniatura (PPTM), potenciais de placa terminal (PPT) e liberação de quanta de acetilcolina na junção neuromuscular, elaboraram três hipóteses em relação à ação da procainamida na junção neuromuscular: 1) inibição na síntese ou na liberação de acetilcolina no neurônio terminal e diminuição da transmissão dos impulsos nervosos; 2) ação estabilizadora da membrana; 3) competição com a acetilcolina pelo receptor nicotínico pós-sináptico. Essa última hipótese também foi confirmada por outros autores ${ }^{7-10}$, mas é contrária aos resultados do presente estudo, uma vez que se observou que a procainamida não causou redução na amplitude das respostas musculares em preparação hemidiafragma de rato cronicamente desnervado nem em preparação Biventer cervicis, demonstrando ausência de efeito competitivo entre a procainamida e a acetilcolina. O músculo Biventer cervicis de pintainho responde à acetilcolina com contração, pois a densidade dos receptores nicotínicos ao longo da fibra muscular é muito maior do que nos músculos de mamíferos. O mesmo pode ser observado no diafragma desnervado, visto que o processo de desnervação promove neoformação de receptores nicotínicos ao longo da fibra muscular, aumentando de forma considerável a sensibilidade dos receptores ao neurotransmissor ${ }^{17}$. A diferença entre as duas preparações está no fato de que no músculo desnervado não existe o terminal pré-sináptico da junção neuromuscular, e os eventos observados nessa preparação refletem efeitos pós-sinápticos.

Neste estudo, a procainamida aumentou a resposta de contração à acetilcolina em Biventer cervicis, efeito não observado em diafragma desnervado. Esse fato leva à suposição de que a procainamida facilita a ação da acetilcolina nos receptores nicotínicos pós-sinápticos, muito provavelmente por um mecanismo pré-sináptico, já que essa facilitação só foi observada na preparação com a inervação íntegra.

Essa ação facilitadora da acetilcolina nos receptores nicotínicos pós-sinápticos também pôde ser constatada pela observação da influência do fármaco sobre os PPTM (Figura 6). A procainamida apresentou resposta bifásica sobre os PPTM. Na primeira fase, ocorreu um aumento na freqüência dos PPTM, que foi seguido de um bloqueio desses potenciais (segunda fase) cerca de 20 minutos após a adição do fármaco. Isso pode ser atribuído a uma característica muito peculiar de receptores do tipo canal iônico, como os da junção neuromuscular, que ficam no estado de dessensibilização, ou seja, refratários a novos estímulos quando são despolarizados por tempo prolongado por seus agonistas ${ }^{18,19}$. A hipótese de estar ocorrendo dessensibilização dos receptores nicotínicos é fundamentalmente reforçada ao se observar que a 4-aminopiridina foi eficaz também na reversão do bloqueio dos PPTM causado pela procainamida ${ }^{18-21}$. Embora a reversão do bloqueio com a 4-aminopiridina seja explicada pelo aumento do aporte de acetilcolina na fenda sináptica quando o potencial de ação é deflagrado, em situações de repouso, o aumento de liberação de acetilcolina não é observado. Na ausência de estimulação nervosa, o 
bloqueio de canais de $\mathrm{K}^{+}$não causa prolongamento da despolarização da membrana, não ocorrendo aumento de entrada de $\mathrm{Ca}^{2+}$ para o terminal pré-sináptico ${ }^{18-20}$. Estudos para investigar o mecanismo pelo qual a 4-aminopiridina reverte a resposta dos receptores da junção neuromuscular indicam que esta possui efeito antagônico sobre a dessensibilização dos receptores da junção neuromuscular ${ }^{18-21}$.

Este estudo mostrou que a interferência da procainamida sobre junção neuromuscular está baseada no mecanismo de dessensibilização dos receptores nicotínicos e aponta fortes indícios de que essa dessensibilização seja secundária a uma ação pré-sináptica da procainamida, que levou a aumento na liberação de acetilcolina para a fenda sináptica. Além disso, o uso concomitante de procainamida e bloqueadores neuromusculares não-despolarizantes, como o rocurônio, ou situações nas quais exista comprometimento da margem de segurança da junção neuromuscular, podem resultar em implicações clínicas que tornam obrigatória a monitorização da transmissão neuromuscular.

\section{Influence of Procainamide on the Neu- romuscular Blockade Caused by Rocu- ronium and Investigation on the Mechanism of Action of Procainamide on the Neuromuscular Junction}

Thalita Duque Martins, M.D.; Yolanda Christina S. Loyola, M.D.; Angélica de Fátima de Assunção Braga, TSA, M.D.

\section{INTRODUCTION}

Procainamide, a synthetic analogue of the local anesthetic procaine, developed for the treatment of ventricular and supraventricular arrhythmias, is longer acting than procaine because its amidic action is resistant to esterases ${ }^{1}$.

Its chronic use may promote the development of antinuclear antibodies with biochemical evidence of a lupus syndrome, which hinders its oral use for a prolonged time. However, intravenously it has been useful in the treatment of cardiac arrhytmias ${ }^{1,2}$.

Some clinical reports demonstrated that high plasma concentrations of procainamide associated with factors that compromise neuromuscular transmission, such as neuromuscular diseases (latent myasthenia gravis without clinical manifestations), drugs, such as amiodarone, diabetes mellitus, and renal failure, can cause myasthenia-like symptoms ${ }^{3-5}$. These effects have been observed in the absence of antiacetylcholine receptor antibodies (Ach) ${ }^{2}$.

Although there are studies trying to explain such effects, the mechanism by which procainamide interferes with neuromuscular transmission is still unknown ${ }^{6-10}$.

It is important to discover the interaction between procainamide and non-depolarizing neuromuscular blockers, which would allow for the safe use of these drugs.
The potentiation of the effects of d-tubocurarine by procainamide has already been shown ${ }^{11}$; however, there is a lack of comparative studies to demonstrate the interactions of procainamide with other neuromuscular blockers used nowadays. Rocuronium is a non-depolarizing, aminosteroid, neuromuscular blocker with an intermediate duration but fast onset of action, which differentiates it from the other non-depolarizing blockers and makes it an alternative agent to succinylcholine in situations of rapid-sequence induction ${ }^{12-14}$.

The aim of this study was to evaluate, in an experimental model, the effects of procainamide in the neuromuscular transmission and its influence on the neuromuscular blockade produced by rocuronium and to investigate the probable mechanism of the interaction between procainamide and rocuronium.

\section{METHODS}

This study complied with the ethical principles of the Colégio Brasileiro de Experimentação Animal (COBEA) approved by the Ethics Commission on Animal Research of the Instituto de Biologia da Universidade Estadual de Campinas (UNICAMP). To assess the effects of procainamide on neuromuscular transmission and its influence on the neuromuscular blockade caused by rocuronium, the rat phrenic nerve diaphragm preparation proposed by Bulbring ${ }^{15}$ was used. Fifteen Wistar rats, weighing 250 to $300 \mathrm{~g}$, were sacrificed under general anesthesia with the intraperitoneal administration of $10 \%$ chloral hydrate $\left(250 \mathrm{mg} \cdot \mathrm{kg}^{-1}\right)$ by bleeding them through the sectioned neck vessels. The hemidiaphragms with the corresponding phrenic nerves were removed and fixed in a basin containing $40 \mathrm{~mL}$ of a nutrient solution of Tyrode with the following composition (in $\mathrm{mM}$ ): $\mathrm{NaCl} 137 ; \mathrm{KCl}$ 2.7; $\mathrm{CaCl}_{2}$ 1.8; $\mathrm{NaHCO}_{3} 11.9 ; \mathrm{MgCl}_{2}$ 0.25; $\mathrm{NaH}_{2} \mathrm{PO}_{4}$ 0.3; and glucose 11 . The solution was aerated constantly with carbogen $\left(95 \% \mathrm{O}_{2}\right.$ and $\left.5 \% \mathrm{CO}_{2}\right)$. The nerve was placed over platinum electrodes connected to a Grass S48 stimulator. The diaphragm was kept under constant tension $(5.0 \mathrm{~g})$ through its tendinous portion by a wire connected to the Load Cell BG59 GMS isometric transducer and submitted to indirect stimulation of $1.0 \mathrm{~Hz}$ and $0.2 \mathrm{msec}$, and tension variations produced by diaphragmatic contractions were recorded by a Gould RS 3400 physiograph.

The rats were divided in three groups ( $n=5$ in each one) according to the drug added to the preparation: Group I procainamide (20 $\left.\mu \mathrm{g} \cdot \mathrm{mL}^{-1}\right)$; Group II - rocuronium $\left(4 \mu \mathrm{g} \cdot \mathrm{mL}^{-1}\right)$; Group III - rocuronium ( $\left.4 \mu \mathrm{g} \cdot \mathrm{mL}^{-1}\right)$ in a preparation exposed previously to procainamide $\left(20 \mu \mathrm{g} \cdot \mathrm{mL}^{-1}\right)$. In Group III (procainamide-rocuronium), the rocuronium was added to the preparation 30 minutes after the procainamide. The neuromuscular responses to indirect stimulation were recorded for 90 minutes after the drugs were added. To revert the neuromuscular blockade produced by the association procainamide-rocuronium, 4-aminopyridine (4-AP) - $20 \mu \mathrm{g} \cdot \mathrm{mL}^{-1}$, was added to the preparation 60 minutes after the neuromuscu- 
lar blockade. The phrenic nerve diaphragm preparation was also used to study the effects of procainamide on miniature end plate potentials (MEPP).

The chick Biventer cervicis preparations $(n=5)$ were assembled according to the method described by Ginsborg ${ }^{16}$ and kept in $5 \mathrm{~mL}$ of a nutrient Krebs solution composed of (in mM): $\mathrm{NaCl} 136 ; \mathrm{KCl} 5.0 ; \mathrm{CaCl}_{2} 2.5 ; \mathrm{KH}_{2} \mathrm{PO}_{4}$ 1.2; $\mathrm{NaHPO}_{3}$ 11.9; and glucose 11.2, under a tension of $5.0 \mathrm{~g}$, temperature of $37^{\circ} \mathrm{C}$, and aerated with carbogen. The muscles received indirect stimulation with supramaximal pulses (intensity of 20-80 V, $0.2 \mathrm{msec}$ duration, and frequency of $0.1 \mathrm{~Hz}$ ). The responses to acetylcholine $\left(10 \mu \mathrm{g} \cdot \mathrm{mL}^{-1}\right)$ were recorded for 30 minutes in a Gould RS 3400 physiograph before and 30 minutes after the addition of procainamide $\left(20 \mu \mathrm{g} \cdot \mathrm{mL}^{-1}\right)$ to the preparation.

For the chronically denervated rat diaphragm preparation, the diaphragms were denervated ${ }^{17}$ and 15 to 30 days later the left hemidiaphragms were removed and placed in a $40 \mathrm{~mL}$ basin containing a nutrient solution of Tyrode, aerated, and kept at $37^{\circ} \mathrm{C}$, as described for the normal preparations. The responses to acetylcholine ( $\left.4 \mu \mathrm{g} \cdot \mathrm{mL}^{-1}\right)$ were recorded by a Gould SR 3400 physiograph before and 30 minutes after the addition of procainamide $\left(20 \mu \mathrm{g} \cdot \mathrm{mL}^{-1}\right)$. Results were expressed as mean and standard deviation. The Student $t$ test was used for the statistical analysis. A level of $5 \%(\alpha=5 \%)$ was considered significant. The test power was calculated and we obtained a $\beta>20 \%$ (power $>80 \%$ ).

\section{RESULTS}

Procainamide at the concentration used in this study and applied to the rat phrenic nerve diaphragm preparation did not reduce the amplitude of the muscular responses to indirect electrical stimulation (Figure 1).

In the preparations exposed previously to procainamide, rocuronium produced a $68.5 \% \pm 7.1 \%$ blockade, with a statistically significant difference $(p=0.0067)$ when compared to the blockade produced by rocuronium alone $(10.4 \% \pm$ $4.5 \%$ ) (Figure 2). 4-aminopyrydine effectively reversed the blockade produced by rocuronium in the preparations exposed to procainamide (Figure 3 ).

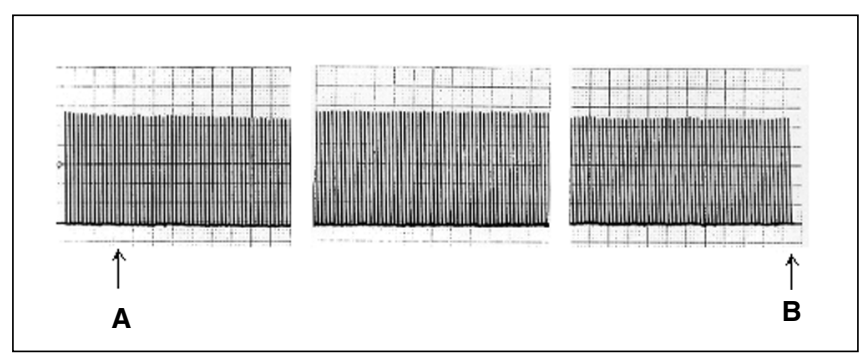

Figure 1 - Effects of Procainamide $\left(20 \mu \mathrm{g} \cdot \mathrm{mL}^{-1}\right)$ on Muscular Responses to Indirect Stimulation in the Rat Phrenic Nerve Diaphragm Preparation. A: addition of procainamide; B: 90 minutes after adding procainamide
In the chick Biventer cervicis preparation, procainamide (20 $\mu \mathrm{g} \cdot \mathrm{mL}^{-1}$ ) increased the contraction provoked by acetylcholine, which was not observed in the chronically denervated rat hemidiaphragm (Figures 4 and 5).

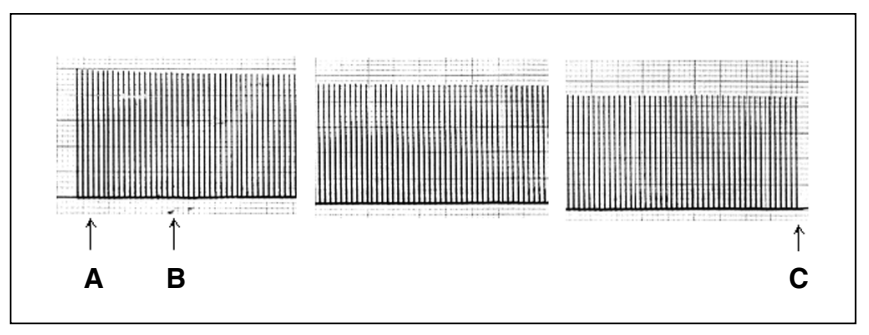

Figure 2 - Effects of Rocuronium (4 $\left.\mu \mathrm{g} \cdot \mathrm{mL}^{-1}\right)$ on Muscular Responses to Indirect Stimulation in the Rat Phrenic Nerve Diaphragm Preparation. A: control; B: addition of rocuronium; C: 90 minutes after adding rocuronium

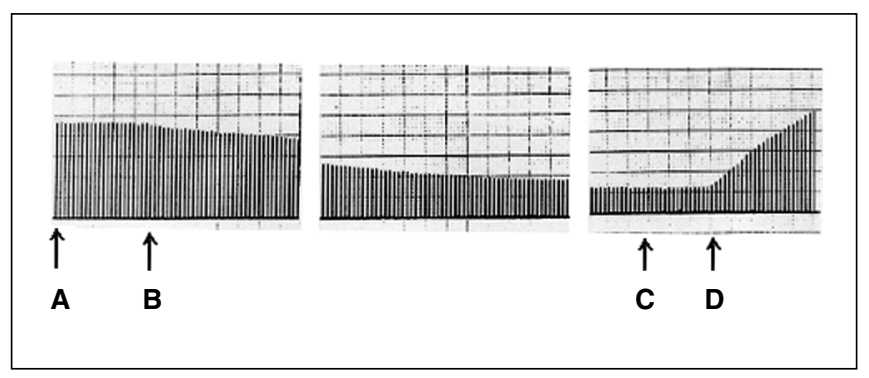

Figure 3 - Effects of Rocuronium (4 $\left.\mu \mathrm{g} \cdot \mathrm{mL}^{-1}\right)$ on Muscular Responses to Indirect Stimulation in the Rat Phrenic Nerve Diaphragm Preparation Exposed to Procainamide $\left(20 \mu \mathrm{g} \cdot \mathrm{mL}^{-1}\right)$. Effects of 4-Aminopyridine. A: control obtained 30 minutes after the addition of procainamide; B: addition of rocuronium; C: neuromuscular blockade after the addition of rocuronium; D: addition of 4 AP (20 $\left.\mu \mathrm{g} \cdot \mathrm{mL}^{-1}\right)$.

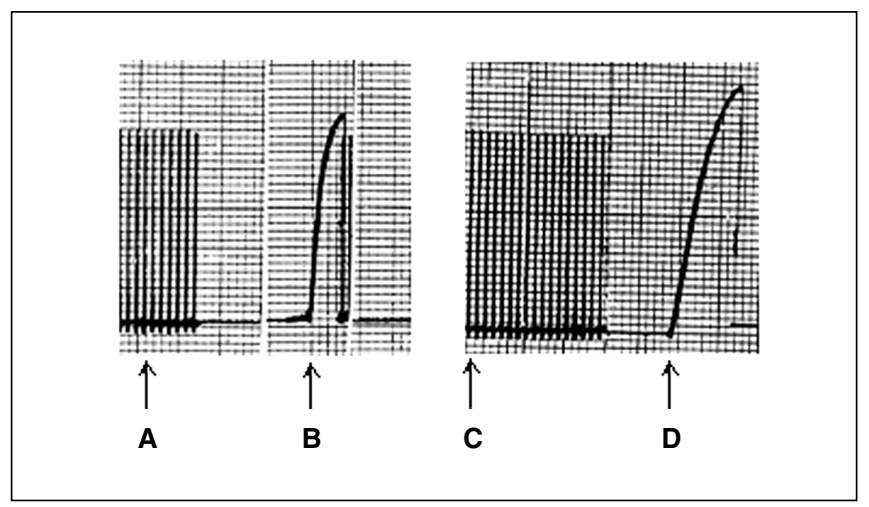

Figure 4 - Effects of Procainamide $\left(20 \mu \mathrm{g} \cdot \mathrm{mL}^{-1}\right)$ on the Contraction Induced by Acetylcholine $\left(10 \mu \mathrm{g} \cdot \mathrm{mL}^{-1}\right)$ in the Chick Biventer cervicis Preparation $(n=5)$ Under Indirect Stimulation (frequency of $0.1 \mathrm{~Hz}$ and duration of $0.2 \mathrm{~ms}$ ). A: control; B: addition of acetylcholine; C: 30 minutes after adding procainamide; $\mathrm{D}$ : addition of acetylcholine 
The effects on the miniature end plate potentials were characterized, initially, by an increase in frequency followed by a blockade 20 minutes after the addition of the drug. This effect was reversed by 4-aminopyridine (Figure 6).

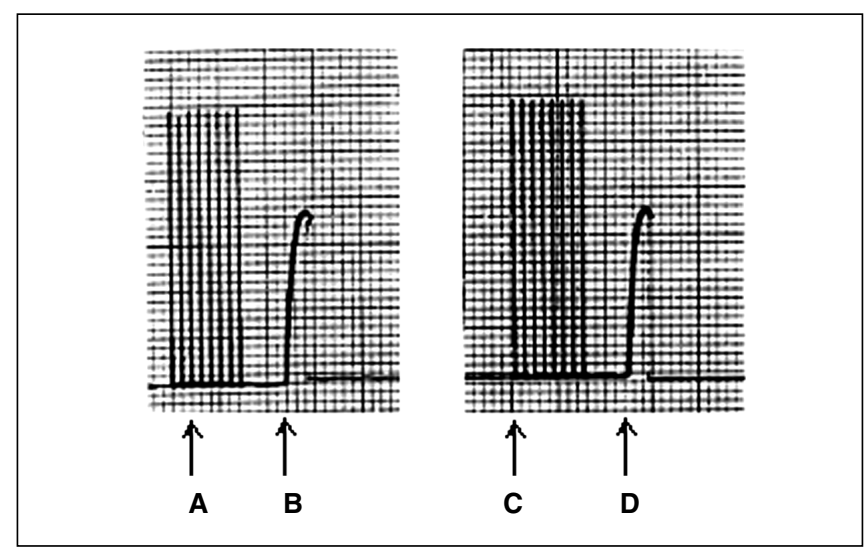

Figure 5 - Effects of Procainamide $\left(20 \mu \mathrm{g} \cdot \mathrm{mL}^{-1}\right)$ on the Contraction Induced by Acetylcholine $\left(4 \mu \mathrm{g} \cdot \mathrm{mL}^{-1}\right)$ on the Chronically Denervated Diaphragm $(n=5)$. A: control; B: addition of acetylcholine; C: 30 minutes after adding procainamide; D: addition of acetylcholine

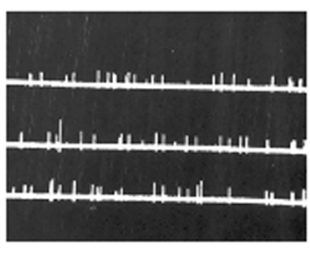

A

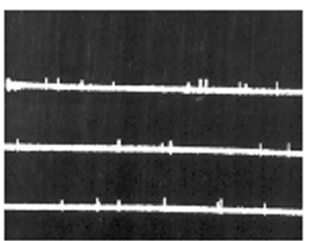

C

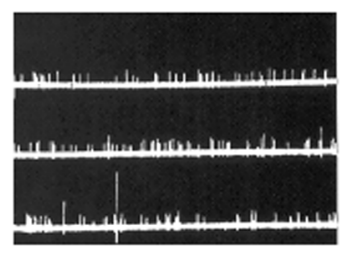

B

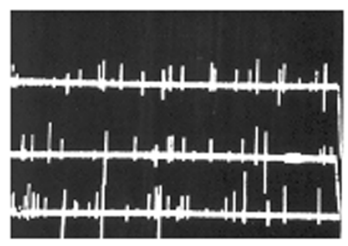

D
Figure 6 - Effects of Procainamide $\left(20 \mu \mathrm{g} \cdot \mathrm{mL}^{-1}\right)$ on Miniature End Plate Potentials (MEPP) in the Rat Phrenic Nerve Diaphragm Preparation. A: control; B: 10 minutes after adding procainamide; C: 20 minutes after adding procainamide; D: effect of 4aminopyridine

\section{DISCUSSION}

Figures 1 and 3 show that procainamide alone does not have a direct effect on neuromuscular transmission, but it is capable of potentiating the blockade caused by rocuronium. These results confirm the results of prior studies demons- trating that procainamide can potentiate the effects of neuromuscular blockers, such as d-tubocurarine ${ }^{11}$. Prolonged exposure to procainamide can reduce the number of receptors in the neuromuscular junction, reducing the safety margin of receptors in this region. This can probably explain the potentiation of the neuromuscular blockade caused by rocuronium ${ }^{11}$.

4-aminopyridine, a plasma membrane $\mathrm{K}^{+}$channel blocker that, in the presence of an action potential, increases the concentration of acetylcholine in the synaptic cleft, antagonized this blockade. The blockade of the $\mathrm{K}^{+}$channels maintains the membrane depolarized for longer and, consequently, the voltage-dependent $\mathrm{Ca}^{++}$channels are opened, increasing the amount of $\mathrm{Ca}^{++}$inside the pre-synaptic terminal, which is directly proportional to the release of neurotransmitter. Initially, the increase in the amount of acetylcholine released induced by 4-aminopyridine, reversing the neuromuscular blockade caused by the interaction rocuronium-procainamide, allows us to infer that this is a competitive blockade. These results are similar to those obtained by Lee et al. ${ }^{6}$ Using a preparation of rat Digitorum longus muscle, they studied the effects of different concentrations of procainamide on miniature end plate potentials (MEPP), terminal plate potentials (TPP), and release of quanta of acetylcholine in the neuromuscular junction, elaborated three hypothesis regarding the actions of procainamide on the neuromuscular junction: 1) inhibits the synthesis or release of acetylcholine in the terminal neuron and reduced transmission of nerve impulses; 2) stabilizes membranes; 3) competes with acetylcholine for the post-synaptic nicotinic receptor.

The last hypothesis was confirmed by other authors ${ }^{7-10}$, but goes against the results of this study, since procainamide did not reduce the amplitude of the muscular responses in the chronically denervated rat hemidiaphragm or in the chick Biventer cervicis preparation, demonstrating the lack of competition between procainamide and acetylcholine.

The chick Biventer cervicis muscle contracts in response to acetylcholine because the density of nicotinic receptors along the muscle fibers is much greater than that of mammalian muscles. The same can be observed in the denervated diaphragm, since the denervation process promotes the neoformation of nicotinic receptors along the muscle fiber, increasing considerably the sensitivity of the receptors to the neurotransmitter ${ }^{17}$. The difference between both preparations is that the denervated muscle lacks the pre-synaptic terminal of the neuromuscular junction and the events observed in this preparation reflect post-synaptic effects.

In this study, procainamide increased the contraction in response to acetylcholine in the chick Biventer cervicis preparation, which was not seen in the denervated diaphragm. This led to the assumption that procainamide facilitates the actions of acetylcholine on post-synaptic nicotinic receptors, most likely through a pre-synaptic mechanism, since the facilitation was observed only in preparations in which the innervation was preserved. 


\section{INFLUENCE OF PROCAINAMIDE ON THE NEUROMUSCULAR BLOCKADE CAUSED BY ROCURONIUM AND INVESTIGATION}

ON THE MECHANISM OF ACTION OF PROCAINAMIDE ON THE NEUROMUSCULAR JUNCTION

This facilitating action of acetylcholine on post-synaptic nicotinic receptors could also be evidenced by the influence of the drug on MEPP (Figure 6). Miniature end plate potentials presented a biphasic response to procainamide. In the first phase, there was an increase in MEPP frequency, followed by a blockade of those potentials (second phase) around 20 minutes after the addition of procainamide. This can be attributed to a peculiar characteristic of ionic type receptors, such as those present in the neuromuscular junction, that remain in a state of desensitization, i.e., refractory to new stimuli when they are depolarized for a prolonged time by their agonists ${ }^{18,19}$.

The hypothesis of nicotinic receptor desensitization is reinforced by observing that 4-aminopyridine was effective in reversing the blockade of MEPP caused by procainamide ${ }^{18-21}$. Although the reversal of the blockade with 4-aminopyridine can be explained by the increased amount of acetylcholine in the synaptic cleft when the action potential is initiated, at rest the amount of acetylcholine is not increased. In the absence of nerve stimulation, the blockade of $\mathrm{K}^{+}$channels does not prolong membrane depolarization and, consequently, there is no $\mathrm{Ca}^{++}$flow into the pre-synaptic terminal ${ }^{18-20}$. Studies to investigate the mechanism by which 4-aminopyridine reverts the response of the receptors in the neuromuscular junction indicate that this drug antagonizes the desensitization of those receptors ${ }^{18-21}$.

This study demonstrated that the interference of procainamide on the neuromuscular junction is based on the desensitization of nicotinic receptors and indicates that this desensitization is secondary to a pre-synaptic action of that drug, which increased the release of acetylcholine into the synaptic cleft. Besides, the concomitant use of procainamide and non-depolarizing neuromuscular blockers, such as rocuronium, or in situations that compromise the safety margin of the neuromuscular junction, can have clinical implications that demand monitoring of the neuromuscular transmission.

\section{REFERÊNCIAS - REFERENCES}

01. Roden DM - Antiarrhythmic Drugs, em: Gilman AG - The Pharmacological Basis of Therapeutics. New York, McGraw-Hill, 1996;868.

02. Blanton CL, Sawyer RA - Myasthenia gravis by another name: an elusive imposter. Surv Ophthalmol, 1993;38:219-226.

03. Miller CD, Oleshansky MA, Gibson KF et al - Procainamideinduced myasthenia-like weakness and dysphagia. Ther Drug Monit, 1993;15:251-254.

04. Miller B, Skupin A, Rubenfire M et al - Respiratory failure produced by severe procainamide intoxication in a patient with preexisting peripheral neuropathy caused by amiodarone. Chest, 1988;94:663-665.

05. Godley PJ, Morton TA, Karboski JA et al - Procainamide-induced myasthenic crisis. Ther Drug Monit, 1990;12:411-414.

06. Lee DC, Kim YI, Liu HH et al - Presynaptic and postsynaptic actions of procainamide on neuromuscular transmission. Muscle Nerve, 1983;6:442-447.
07. Manani G, Gritti G, Scalella P et al - Neuromuscular paralyzing activity of procaine amide. Experimental study. Acta Anaesthesiol, 1968;19:(Suppl7):43-63.

08. Galzigna L, Manani G, Mammano S et al - Experimental study on the neuromuscular blocking action of procaine amide. Agressologie, 1972;13:107-116.

09. Ferraro MV, Manani G, Battocchio G et al - Interference of procaine amide with cholinergic mechanisms. Agressologie, 1972; 13:165-170.

10. Miledi R, Potter LT - Acetylcholine receptors in muscle fibres. Nature, 1971;233:599-603.

11. Fontana MD, Vital Brazil O - Mecanismo da potencialização causada pela quinidina e procainamida sobre o bloqueio neuromuscular produzido pela d-tubocurarina. Ciência e Cultura 1973; 25:485.

12. Yorukoglu D, Asik Y, Okten F - Rocuronium combined with i.v. lidocaine for rapid tracheal intubation. Acta Anaesthesiol Scand, 2003;47:583-587.

13. Engbaek J, Viby-Mogensen J - Can rocuronium replace succinylcholine in a rapid-sequence induction of anaesthesia? Acta Anaesthesiol Scand, 1999;43:1-3.

14. Andrews JI, Kumar N, Van Den Brom RH et al - A large simple randomized trial of rocuronium versus succinylcholine in rapidsequence induction of anaesthesia along with propofol. Acta Anaesthesiol Scand, 1999;43:4-8.

15. Bulbring $\mathrm{E}$ - Observation on the isolated phyrenic nerve diaphragm preparation of the rat. $\mathrm{Br} \mathrm{J}$ Pharmacol, 1997; 120(Suppl4):3-26.

16. Ginsborg BL, Warriner $\mathrm{J}$ - The isolated chick biventer cervicis nerve-muscle preparation. Br J Pharmacol Chemother, 1960; $15: 410-411$

17. Vital Brazil O - Ação neuromuscular da peçonha de Micrurus. Hospital, 1965;69:183-224.

18. Wang $\mathrm{H}$, Sun $\mathrm{X}$ - Desensitized nicotinic receptors in brain. Brain Res Brain Res Rev, 2005;48:420-437.

19. Brazil OV, Fontana MD, Heluany NF - Nature of the postsynaptic action of crotoxin at guinea-pig diaphragm end-plates. J Nat Toxins, 2000;9:33-42.

20. Vital Brazil O, Fontana MD, Pavani NJ - Effect of 4-aminopyridine on end-plate receptor desensitization caused by carbachol. Eur J Pharmacol, 1982;86:199-205.

21. Vital Brazil O, Fontana MD - Effect of 4-Aminopyridine on the Desensitization of the Rat Diaphragm caused by Carbacol, em: Lechat P - Aminopyridines and Similarly Acting Drugs; Effects on Nerves, Muscles and Synapses. Oxford, Pergamon, 1982;240.

\section{RESUMEN}

Martins TD, Loyola YCS, Braga AFA — Influencia de la Procainamida sobre el Bloqueo Neuromuscular Producido por el Rocuronio e Investigación sobre el Mecanismo de Acción de la Procainamida en la Junción Neuromuscular.

JUSTIFICATIVA Y OBJETIVOS: La potenciación de la procainamida sobre el bloqueo neuromuscular producido por la d-tubocurarina ya está comprobada, pero sin embargo el mecanismo es controvertido. El objetivo del estudio fue el de evaluar la influencia de la procainamida en el bloqueo neuromuscular producido por el rocuronio e investigar los mecanismos de esa interacción.

MÉTODO: Se utilizaron 15 ratones (250 a $300 \mathrm{~g}$ ) en preparación descrita por Bülbring. Se formaron los siguientes grupos $(n=5$ cada): procainamida - $20 \mu \mathrm{g} \cdot \mathrm{mL}^{-1}$ (Grupo I); rocuronio $-4 \mu \mathrm{g} \cdot \mathrm{mL}^{-1}$ (Grupo II) y rocuronio - $4 \mu \mathrm{g} \cdot \mathrm{mL}^{-1}$ y procainamida $-20 \mu \mathrm{g} \cdot \mathrm{mL}^{-1}$ (Gru- 
po III). Se evaluó: 1) la amplitud de las contracciones musculares bajo la estimulación indirecta en cada grupo, antes y después de la adición de los fármacos; 2) los potenciales de placa terminal en miniatura (PPTM); 3) la eficacia de la 4-aminopiridina en la reversión del bloqueo neuromuscular. El mecanismo de la interacción se estudió en Biventer cervicis $(n=5)$ y diafragma de ratón desnervado $(n=5)$, observándose la influencia de la procainamida en la respuesta a la acetilcolina antes y después de la adición de la procainamida.

RESULTADOS: De forma aislada, la procainamida no alteró las respuestas neuromusculares. El bloqueo producido con el Grupo III fue de $68,6 \% \pm 7,1 \%$, con una diferencia significativa $(p=0,0067)$ con relación al Grupo II (10,4\% $\pm 4,5 \%)$, revertido por la 4-aminopiridina. La procainamida ocasionó un aumento en la frecuencia de los PPTM, seguido de bloqueo revertido por la 4-aminopiridina. En Biventer cervicis, la procainamida aumentó la respuesta a la acción de contracción de la acetilcolina, resultado no observado con el diafragma desnervado.

CONCLUSIONES: La procainamida potenció el bloqueo producido por el rocuronio. Las alteraciones observadas con PPTM y Biventer cervicis identificaron una acción presináptica. El antagonismo de la 4-aminopiridina sobre el bloqueo de los PPTMs sugirió la desensibilización de los receptores por la procainamida. 